\title{
Macroinvertebrate assemblages along a land-use gradient in the upper River Njoro watershed of Lake Nakuru drainage basin, Kenya
}

\author{
Samuel Kibichii, ${ }^{1 *+}$ William A. Shivoga, ${ }^{2}$ Mucai Muchiri ${ }^{1}$ and Scott N. Miller ${ }^{3}$ \\ ${ }^{1}$ Department of Fisheries, Moi University, PO Box 1125, Eldoret, Kenya, ${ }^{2}$ Department of Environmental Science, \\ Egerton University, PO Box 536, Njoro, Kenya, and ${ }^{3}$ Department of Renewable Resources, University of \\ Wyoming, Laramie, Wyoming, USA
}

\begin{abstract}
A study was conducted in the upper reaches of the River Njoro watershed to test the impacts of changing land-use patterns, from predominantly forest to pasture and agriculture, on benthic macroinvertebrate communities. Stream sampling sites were chosen to correspond to the main offstream land uses, including forests, grazing, small-scale agriculture, and intensive agriculture. Physicochemical variables were measured at each sampling site, and from collected water samples. Sampled macroinvertebrates were identified, and taxon diversity, richness, evenness and dominance were estimated for each site. Higher mean temperatures were recorded at the grazed and cultivated sites, compared to the forested sites. Higher ammonia concentrations were characteristic of the grazed parts of the watershed, while higher mean total phosphorus and total nitrogen concentrations were observed at the intensively cultivated sites. Baetis and Simulidae composed $65 \%$ by number of all the invertebrates collected. They dominated the benthos of the cultivated sections of the watershed, where they formed up to $75 \%$ of the observed invertebrate numbers. However, higher mean diversities, richness and evenness were recorded at forested sites, with a few taxa (notably Lepidostoma hirtum, Potamon sp., Leptophlebia sp. and Helodidae) being restricted to these unpolluted reaches, although many other taxa were common to all sites. Our findings suggest that a change from forestry to agriculture and grazing land uses have affected the physicochemical environment of the River Njoro, leading to a reduction in the diversity and evenness of benthic macroinvertebrates.
\end{abstract}

\section{Key words}

benthic macroinvertebrates, community structure, land-use change.

\section{INTRODUCTION}

In recent years, there have been calls for broader, more holistic approaches to aquatic ecosystem management for the conservation of biodiversity, with emphasis on maintaining the ecological integrity of streams (Wells et al. 2002) and their receiving waterbodies (Wetzel 2001). Not unexpectedly, the character of a stream is determined by the character and magnitude of the basin draining into it,

*Corresponding author. Email: samuel.kibichii@ucd.ie

${ }^{\dagger}$ Present address: Research Lab 2, School of Biology and Environmental Science, National University of Dublin,

Belfield, Dublin 4, Ireland

Accepted for publication 7 May 2007. mainly because running water ecosystems are intimately tied to physical, chemical and biological processes that occur throughout the catchment (Gore \& Shields 1995). These processes, in turn, influence ecosystems of the receiving lakes, and can limit productivity, or lead to loss of biodiversity as the pollution from landscape changes in the drainage basin increases (Allan 1995).

The ubiquitous and sedentary nature of benthic macroinvertebrates (Rosenbereg \& Resh 1992), as well as their measurable responses to ambient conditions and exposure over time (Wells et al. 2002), facilitates their use as important environmental indicators in stream ecosystem monitoring. As a result of the restricted mobility and habitat preferences associated with the benthos, they are subjected to the full rigour of their local environments (Jones et al. 2002). Subsequently, they also can change in composition and 
distribution with changes in their surrounding environmental conditions (Carlisle et al. 2003).

When observed patterns of macroinvertebrate community assemblages are related to offstream activities (e.g. land use and in-stream habitat conditions, using physicochemical parameters), ecosystem effects of ecological stress can be discerned. Regardless of how a range of human influences is selected among study sites, sampling sites that are subjected to differing intensities and types of human activity are essential to detect and understand the human influences on them (Simon 2003). In this study, sampling and analysis will concentrate on multiple sites within the same environmental setting (e.g. within the same reach in a catchment) across a range of conditions, from least impacted to severely disturbed as a result of human activities (Carlisle et al. 2003). Accordingly, sampling sites in this study were concentrated in the upper reaches of River Njoro.

Land use in the Lake Nakuru basin has been changing since the beginning of the last century, following largescale settlement by colonial farmers in the middle reaches of the watershed, and later in the 1970s and 1980s by indigenous farmers on former settler farms and adjacent forest reserves in the upper reaches. The effects of these land uses on the stream ecosystem have never been investigated, although an introduced trout has already disappeared from the river following these changes. This study focuses on the upper River Njoro as an indicator of ecosystem responses to land-use changes in the Lake Nakuru drainage basin. This study has three primary objectives: (i) to determine the physicochemical conditions of the river; (ii) to determine the community assemblages of benthic macroinvertebrates; and (iii) to assess the relationships between physicochemical parameters and the macroinvertebrate community assemblages along a landuse gradient evident in the watershed.

\section{METHODS}

River Njoro is the largest single contributor in Kenya of run-off to Lake Nakuru. The River $\left(0^{\circ} 30^{\prime} \mathrm{S}, 35^{\circ} 20^{\prime} \mathrm{E}\right)$ is $50 \mathrm{~km}$ long, and originates in the Mau escarpment at $\approx 3000 \mathrm{~m}$ a.s.l. It terminates in Lake Nakuru at $1759 \mathrm{~m}$ a.s.l. The river drains a complex landscape mosaic of both established and newly created agricultural fields, grazing pastures, urban settings, and forests. The majority of run-off is generated in the upper portions of the watershed, which were historically forested with both native and plantation forests (Baldyga et al., in press). Eleven sampling sites were chosen across this upper portion of the watershed, to coincide with the major land-use types (see Table 1 and Fig. 1). Runguma and Salt Spring were chosen as 'unpolluted references' to represent conditions of the river where indigenous forest was the dominant land cover. Logoman and Tiriytagoi were chosen to represent conditions at sites dominated by grazing, while Sigotik upstream, bridge and downstream, and Nessuit Bridge, were selected to represent newly cultivated portions of the watershed that exhibited less-intensive practices and intact riparian corridors. Forest Camp, Highland Flowers and Confluence upstream represented parts of the watershed settled earlier, and where agricultural activities have intensified, including the introduction of greenhouse-produced flowers and cultivation of riparian forest corridors.

The river was sampled twice in April and May and once in June, July and August 2003. At each sampling site, temperature $\left({ }^{\circ} \mathrm{C}\right), \mathrm{pH}$, conductivity $\left(\mu \mathrm{S} \mathrm{cm}{ }^{-1}\right)$, dissolved

Table 1. Descriptions of sampling sites in the upper reaches of the River Njoro, Kenya

\begin{tabular}{|c|c|c|c|c|c|c|c|c|c|}
\hline \multirow[b]{2}{*}{$\begin{array}{l}\text { Characteristic } \\
\text { land use }\end{array}$} & \multirow[b]{2}{*}{ Sampling site } & \multirow[b]{2}{*}{$\begin{array}{l}\text { Altitude } \\
\text { (m a.s.I.) }\end{array}$} & \multirow[b]{2}{*}{$\begin{array}{l}\text { Grassland/ } \\
\text { pasture }\end{array}$} & \multirow[b]{2}{*}{$\begin{array}{c}\text { Dense } \\
\text { vegetation }\end{array}$} & \multicolumn{3}{|c|}{ Percentage land-use cover } & \multirow[b]{2}{*}{$\begin{array}{l}\text { Large-scale } \\
\text { agriculture }\end{array}$} & \multirow[b]{2}{*}{$\begin{array}{l}\text { Small-scale } \\
\text { agriculture }\end{array}$} \\
\hline & & & & & $\begin{array}{l}\text { Plantation } \\
\text { forest }\end{array}$ & $\begin{array}{l}\text { Riparian } \\
\text { forest }\end{array}$ & $\begin{array}{l}\text { Degraded } \\
\text { lands }\end{array}$ & & \\
\hline \multirow[t]{2}{*}{ Forestry } & Salt Spring & 2600 & 2 & 95 & 0 & 3 & 0 & 0 & 0 \\
\hline & Runguma & 2660 & 3.1 & 84.4 & 6 & 5.4 & 0.1 & & 1 \\
\hline \multirow[t]{2}{*}{ Grazing } & Logoman & 2685 & 30 & 30.3 & 26.7 & 0 & 3.3 & 2 & 8 \\
\hline & Tiriytagoi & 2701 & 28.4 & 31.3 & 26.3 & 1.5 & 3.2 & 1.9 & 7.4 \\
\hline Small-scale & Nessuit Bridge & 2420 & 4.7 & 74.5 & 1.3 & 5.1 & 0 & 0.5 & 14 \\
\hline \multirow[t]{3}{*}{ agriculture } & Sigotik Upstream & 2417 & 18 & 48.4 & 19.5 & 2.6 & 1.7 & 1.2 & 7.5 \\
\hline & Sigotik Bridge & 2408 & 19 & 48.4 & 19.5 & 2.6 & 1.8 & 1.2 & 7.5 \\
\hline & Sigotik Downstream & 2402 & 18 & 48.4 & 19.5 & 2.6 & 1.7 & 1.2 & 7.5 \\
\hline Intensive & Highland Flowers & 2337 & 19 & 46.6 & 18.8 & 2.6 & 1.6 & 1.6 & 10 \\
\hline \multirow[t]{2}{*}{ agriculture } & Confluence Upstream & 2320 & 17.5 & 42.9 & 17.2 & 0 & 1.5 & 11.5 & 9.4 \\
\hline & Forest Camp & 2335 & 1 & 57.3 & 2.9 & 3.8 & 0.8 & 1.7 & 32.4 \\
\hline
\end{tabular}


oxygen (DO) saturation (\%), and DO concentration $\left(\mathrm{mg} \mathrm{L}^{-1}\right)$ were measured in situ using a calibrated Jenway 3405 electrochemical analyser (Barloword Scientific Ltd, Dunmow, Essex, UK). Total phosphorus ( $\mathrm{m} \mathrm{L} \mathrm{L}^{-1}$ ), total nitrogen (mg $\left.\mathrm{L}^{-1}\right)$, ammonium nitrogen $\left(\mathrm{NH}_{3}-\mathrm{N} ; \mathrm{mg} \mathrm{L}^{-1}\right)$, nitrite nitrogen $\left(\mathrm{NO}_{2}-\mathrm{N} ; \mathrm{mg} \mathrm{L}^{-1}\right)$, nitrate nitrogen $\left(\mathrm{NO}_{3}-\mathrm{N} ; \mathrm{mg} \mathrm{L}^{-1}\right)$, total suspended solids (TSS; $\mathrm{mg} \mathrm{L}^{-1}$ ) and total organic carbon (TOC; $\mathrm{mg} \mathrm{L}^{-1}$ ) concentrations were determined at the water quality testing laboratory at Lake Nakuru, using samples obtained from each site. All analyses were done following standard methods as outlined in APHA (1998).

Benthic macroinvertebrates were sampled quantitatively, using a modified Hess sampler with a circular sampling area of $0.27 \mathrm{~m}^{2}$ and a $100-\mu \mathrm{m}$ mesh size net placed on the streambed. The area enclosed was agitated by hand, with sediments, organic debris and associated macroinvertebrates being dislodged and washed into a removable end-jar. The jar was then removed and its contents were washed into 1-L polyethylene bottles. Ten per cent formaldehyde solution was then added, and the samples were transported to the laboratory. To increase the probability of including as many taxa as possible, samples were taken from a stretch consisting of a pool, riffle and the transition zone, so that three benthic samples were obtained at each site. At each pool, transition area and riffle, the sampler was placed at four different points at random to obtain the invertebrates, which were then pooled to form a single sample. Samples were then poured into Petri dishes in the laboratory, and sorted under a stereomicroscope (Leica Zoom model 2000, Leica Microsystems, Leica Microsystems, Wetzar, Germany). Encountered organisms were counted and preserved in glass vials for each sample, using a 70\% ethanol solution. Samples with large quantities of sediment and organic debris were subsampled by dividing each sample into four equal parts, from which one part was chosen randomly and processed.

Selected macroinvertebrates were identified according to the methods of Savage (1989), Edington and Hildrew (1995), Wallace et al. (1990), and an identification key of the international postgraduate training course in limnology (Vienna, Austria). Because of a paucity of published literature and taxonomic keys of the Kenyan stream fauna, most specimens were assigned only to the lowest taxon within which they could be placed with certainty. Subsequently, many specimens were identified only to family, and a few to genus levels. Members of the family Chironomidae were identified to subfamily and, when possible, to tribe.
Fig. 1. Sampling sites in the River Njoro watershed (sites are located in the upper portion of the watershed (italics) in the region of the Lake Nakuru basin that have undergone the most significant land-cover change over the past decade).

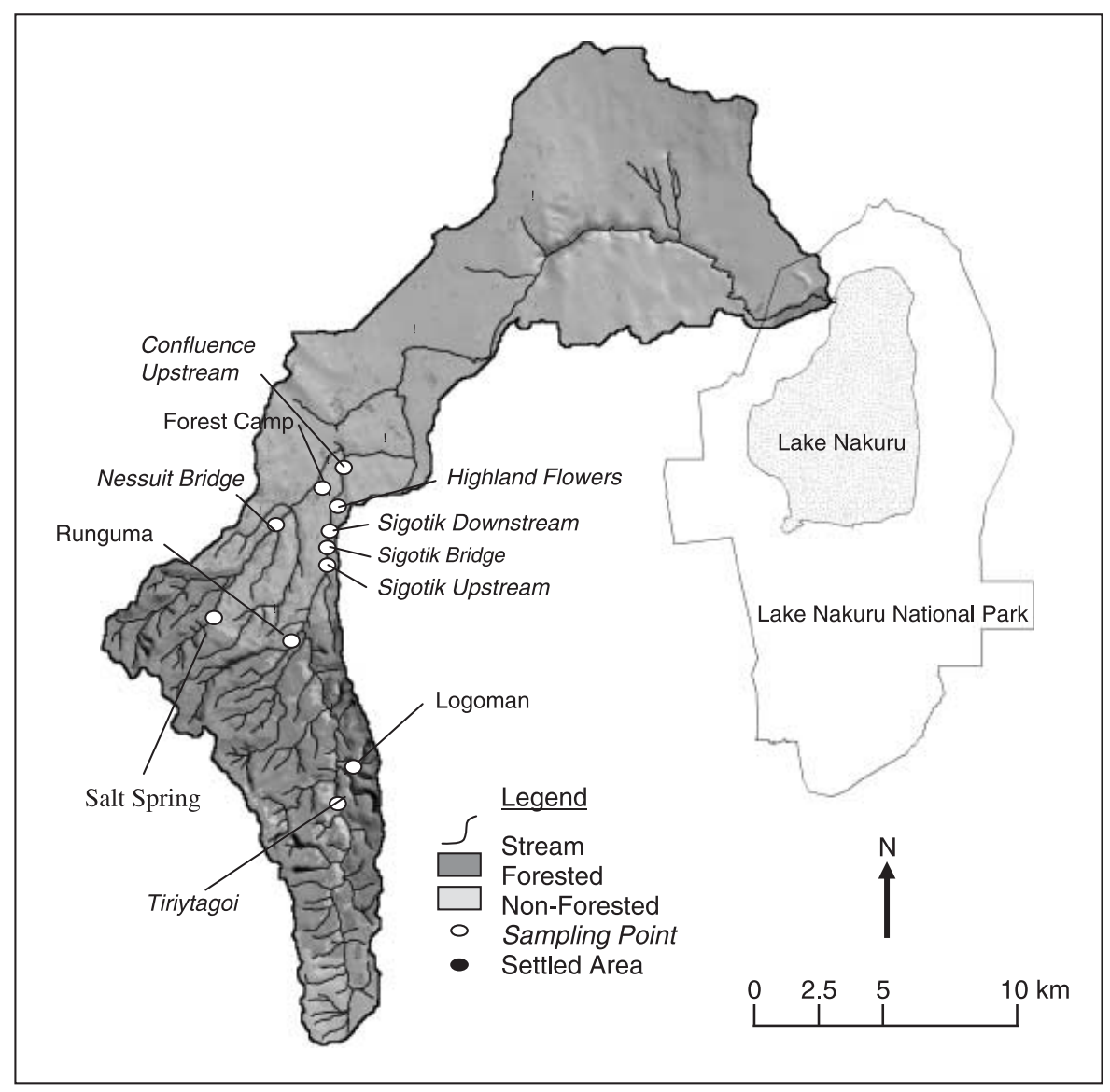

(C) 2007 Blackwell Publishing Asia Pty Ltd 
To characterize sites and identify suitable biological indicators of human impacts, five community attributes were calculated for each sample collected at a site, as follows:

1. Density: Calculated as individuals per square meter of stream bed.

2. Richness: Using Margalef's index (d), calculated as: $\mathrm{d}=(\mathrm{s}-1) \log \mathrm{N}^{-1}$, where $\mathrm{s}=$ number of taxa present in the sample; $\mathrm{N}=$ total number of individuals; and $\mathrm{d}=$ a measure of the number of taxa for a given number of individuals present, and reduces the dependence of the number of taxa on sample size (Brower et al. 1990).

3. Diversity: Using the Shannon diversity index $\left(\mathrm{H}^{\prime}\right)$, calculated as: $\mathrm{H}^{\prime}=-\Sigma \mathrm{p}_{\mathrm{i}} \log \mathrm{p}_{\mathrm{i}}$ (Brower et al. 1990), where $\mathrm{p}_{\mathrm{i}}=$ the proportion of the $\mathrm{i}^{\text {th }}$ taxon; and $\Sigma=$ the summation of all values from the first to the $\mathrm{i}^{\text {th }}$ taxon encountered.

4. Evenness (J): Calculated as: $\mathrm{J}=\mathrm{H}^{\prime} / \mathrm{H}_{\max }$, where $\mathrm{H}^{\prime}=$ hannon diversity index for the sample; $\mathrm{H}_{\max }=$ maximum possible diversity for a collection of $\mathrm{N}$ individuals in a sample. $\mathrm{H}_{\max }$ was calculated as $\mathrm{H}_{\max }=\log \mathrm{s}$ (Brower et al. 1990).

5. Dominance $\left(\mathrm{J}^{\prime}\right)$ : Calculated on the basis of evenness (J) as: $\mathrm{J}^{\prime}=1-\mathrm{J}$ (Brower et al. 1990), and was estimated for each sample at a site. The means ( \pm standard errors) were calculated for each physicochemical parameter, richness and diversity per station. Analysis of variance (one-way ANovA; Zar 1996) was used to test for difference between sites for each parameter. Duncan's multiple range test was further used to determine specific sites differing significantly from each other. Density, evenness and dominance data were tested using a non-parametric Kruskal-Wallis ANova (Zar 1996). Median percentage contribution of the ten most-abundant taxa also was used to compare the sampling sites in the forested, grazed and cultivated parts of the watershed. Spearman rank order correlations (Zar 1996) were used to relate community attributes with physicochemical variables. All analyses were carried out using STATISTICA for windows software package (StatSoft 2001).

\section{RESULTS \\ Physicochemical variables}

Table 2 summarizes the physicochemical parameters for the sites sampled in this study. Sites in forested parts of the watershed had significantly lower water temperature than those in grazed and cultivated parts $(P<0.05)$, except for Nessuit Bridge. All the sampled sites had high DO concentrations (above $100 \%$ saturation; Table 2) throughout the study period. The measured conductivity did not show any particular relationship to land-use-specific patterns. However, all sites along the main tributary had lower conductivity values than the Little Shuru tributary (Salt Spring, Nessuit Bridge and Forest Camp) on all sampling dates. Likewise, higher mean

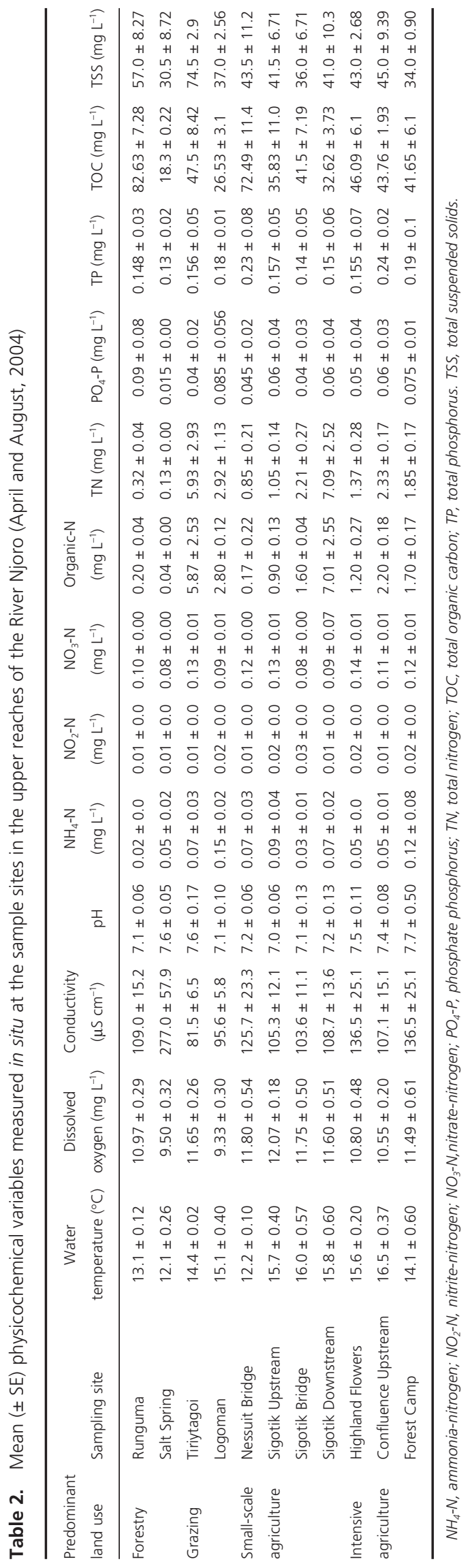


$\mathrm{pH}$ values were recorded at the Little Shuru sites than at all the other sites, although a down- or upstream pattern in the $\mathrm{pH}$ was not evident. Furthermore, no discernable patterns were observed between spatial variations in mean $\mathrm{pH}$ and land use.

The nitrate concentration was particularly lower at Salt Spring, Runguma and Logoman, and elevated at Highland Flowers, Nessuit Bridge, Sigotik Upstream and Forest Camp $(P<0.05)$. As these latter sites are located in cultivated parts of the watershed, it is most probable that this phenomenon is related to both crop production and livestock concentration, especially downstream of Tiriytagoi. The nitrite and ammonium concentrations were low (mean $<0.1 \mathrm{mg} \mathrm{L}^{-1}$ ) at all sampling sites, except for Logoman, which exhibited a mean concentration of $0.15 \pm 0.04 \mathrm{mg} \mathrm{L}^{-1} \mathrm{NH}_{4}-\mathrm{N}$ (Table 2). This site was heavily grazed because of its open-glade grasslands favoured by Maasai herdsmen. Thus, the elevated ammonia concentration might have been caused by dung and other cattle excreta deposited on and along the stream at the sampling site. The Sigotik Downstream and Tiriytagoi sampling sites exhibited significantly higher mean total organic nitrogen concentrations than all the other sites $(P=0.0001)$. The Logoman $\left(2.8 \pm 0.12 \mathrm{mg} \mathrm{L}^{-1}\right)$ and Runguma $\left(0.20 \pm 0.04 \mathrm{mg} \mathrm{L}^{-1}\right)$ sites also exhibited significantly lower means than Sigotik Downstream and Tiriytagoi $(P=0.0001)$. The total nitrogen concentration followed the same trends, with the higher total organic nitrogen concentration being recorded in grazed and cultivated parts of the watershed than in the forested reference conditions.

Very low orthophosphate-phosphorus concentrations were observed at all sites sampled (Table 2). The Runguma and Salt Spring sites had significantly lower $(P=0.0001)$ mean total phosphorus concentrations, compared to sites in cultivated parts of the watershed, such as Confluence Upstream, Nessuit Bridge and Forest Camp, which recorded significantly higher mean values $(P<0.05)$. It was interesting to note that the difference between the two reference sites and grazed sites was only marginal, suggesting that grazing as a land-use activity could not be a major source of phosphorus enrichment of the stream. The Runguma site exhibited significantly higher TOC concentrations than all other sites sampled (mean $=82.63 \pm 14.03 \mathrm{mg} \mathrm{L}^{-1}$; Table 2 ; $P<0.05)$. This concentration is almost twice the values recorded at the other sites in the watershed, except for Nessuit Bridge. Significantly lower mean TSS concentrations $\left(30.5 \pm 8.72 \mathrm{mg} \mathrm{L}^{-1}\right)$ were recorded at the Salt Spring site, followed by Forest Camp (Table 2).

\section{Benthic macroinvertebrates}

A total of 22892 macroinvertebrates, belonging to 70 taxa, were encountered in samples collected from the upper reaches of River Njoro over the period of this study. The nymphs of the mayfly (Ephemeroptera) Baetis sp. were the most abundant taxon, accounting for $38 \%$ in numbers, followed by the blackfly (Diptera) larvae Simulidae (31\%). Together with larval Chironomidae (Tanytarsini, Tanypodinae and Chironomini), Caenis sp., Ostracoda, Sphaeridae, Lumbriculidae and Hymanella sp., they composed the ten most abundant taxa, accounting for $\sim 95 \%$ in numbers of all the collected invertebrates. These ten taxa also occurred at all the sites sampled.

The highest macroinvertebrate density (69 600 individuals $\mathrm{m}^{-2}$, Table 3) was observed at Highland Flowers in April,

Table 3. Summary of taxa composition, density (individuals $\mathrm{m}^{-2}$ ) and distribution of main taxa of benthic macroinvertebrates at sample sites in upper reaches of Njoro River during study period

\begin{tabular}{|c|c|c|c|c|c|c|c|c|}
\hline Land use & Sampling site & $\begin{array}{c}\text { Highest } \\
\text { density } \\
\text { (individuals } \\
\mathrm{m}^{-2} \text { ) }\end{array}$ & $\begin{array}{c}\text { Lowest } \\
\text { density } \\
\text { (individuals } \\
\mathrm{m}^{-2} \text { ) }\end{array}$ & $\begin{array}{c}\text { Cumulative } \\
\text { number } \\
\text { of taxa }\end{array}$ & $\begin{array}{c}\text { Cumulative } \\
\text { number of } \\
\text { Ephemeroptera } \\
\text { taxa }\end{array}$ & $\begin{array}{l}\text { Cumulative } \\
\text { number of } \\
\text { Trichoptera } \\
\text { taxa }\end{array}$ & $\begin{array}{l}\text { Cumulative } \\
\text { number of } \\
\text { Diptera taxa }\end{array}$ & $\begin{array}{l}\text { Cumulative } \\
\text { number of } \\
\text { coleopters } \\
\text { taxa }\end{array}$ \\
\hline & Salt Spring & 12800 & 400 & 36 & 6 & 8 & 9 & 4 \\
\hline \multirow[t]{2}{*}{ Forestry } & Runguma & 5000 & 200 & 32 & 3 & 7 & 8 & 2 \\
\hline & Tiriytagoi & 8900 & 300 & 26 & 2 & 4 & 7 & 2 \\
\hline \multirow[t]{3}{*}{ Grazing } & Logoman & 11900 & 100 & 33 & 2 & 3 & 12 & 3 \\
\hline & Nessuit Bridge & 11800 & 100 & 20 & 3 & 3 & 9 & 1 \\
\hline & Sigotik Upstream & 17800 & 500 & 36 & 4 & 7 & 6 & 7 \\
\hline Small-scale & Sigotik Bridge & 5900 & 200 & 29 & 3 & 4 & 6 & 2 \\
\hline \multirow[t]{2}{*}{ agriculture } & Sigotik Downstream & 35700 & 600 & 25 & 3 & 3 & 8 & 2 \\
\hline & Highland Flowers & 69600 & 300 & 40 & 3 & 4 & 10 & 8 \\
\hline Intensive & Confluence Upstream & 6500 & 100 & 30 & 3 & 6 & 6 & 4 \\
\hline agriculture & Forest Camp & 5000 & 200 & 29 & 3 & 6 & 8 & 5 \\
\hline
\end{tabular}


the driest month. The lowest density (100 individuals $\mathrm{m}^{-2}$ ) were recorded at Confluence Upstream in May during the wettest month of the study period. The highest abundance recorded in the forested parts of the watershed was 12800 individuals $\mathrm{m}^{-2}$ at the Salt Spring sampling site in August The lowest abundance (200 individuals $\mathrm{m}^{-2}$ ) was observed at the Runguma site in May, the wettest month of the year. At the grazed sites, the highest benthic macroinvertebrate density (19 400 individuals $\mathrm{m}^{-2}$ ) was recorded in June at the Logoman site, while the lowest density (200 individuals $\mathrm{dm}^{-2}$ ) was recorded in the last week of May immediately after heavy rains at the same site.

Thus, the highest abundance of macroinvertebrates in the upper watershed of River Njoro was generally recorded during the dry season, while the lowest was observed during the wettest month of the year, both in the cultivated parts of the watershed. It also can be deduced that, at sites occurring in the least-impacted parts of the watershed, the variation between the highest and lowest densities is smaller than the range at the cultivated sites. Cumulatively, the highest number of macroinvertebrate taxa (40) was recorded at the Highland Flowers site. However, eight of this number were adult beetles (Coleoptera) that were observed only once during the first sampling occasion and were never again encountered. This reduces the number of actual taxa found inhabiting this site to a total of 32 .

Overall, the highest number of taxa belonging to the insect order Ephemeroptera was observed at the Salt Spring sampling site, with Oligoneuriella sp. and Ephemera sp. occurring exclusively there. This site also exhibited the highest number of taxa of the insect order Trichoptera. Curculionidae, Dyopidae and Laccophilidae occurred exclusively at the Highland Flowers site. However, because these taxa occurred at very low abundances (one or two individuals each), and were only encountered during the first sampling occasion, no statistical comparison of sites could be made. The Logoman site had the highest number of taxa belonging to the insect order Diptera. Non-insect taxa, such as Turbellaria (Hymanella sp., Mesostoma sp. and Catenulla sp.), Oligochaeta (Lumbriculidae, Tubificidae and Naididae), Nematoda, Mollusca (Gastropoda and Sphaeridae), Crustacea (Cyclopoida and Ostracoda), and Hydracarina, occurred in low abundances and did not exhibit any land-use-specific patterns.

The freshwater crab (Potamon sp.), however, was observed in large numbers at the uppermost, least-impacted sites (Tiriytagoi, Runguma and Salt Spring). None or one or two individuals per sample were observed at sites under small-scale agriculture, and none at all in the intensively cultivated parts of watershed. They occurred in particular abundance at the Salt Spring and Runguma sites. Likewise, the seemingly rare mayfly nymph, Leptophlebia sp., occurred almost exclusively at the Salt Spring, Runguma and Logoman sites. Its presence in low numbers at the Nessuit Bridge and Forest Camp sites suggests that the individuals collected were washed downstream from the Salt Spring site, where an established population was observed. The larval caddisfly (Trichoptera) Lepidostoma hirtum Fabricius occurred in large numbers in the forested upstream sites (Runguma and Salt Spring), but rarely at the sites along cultivated parts of the watershed. The Coleoptera family, Helodidae, also occurred almost exclusively at the Runguma and Salt Spring site, implying these taxa are sensitive to land-use changes, as they occurred only rarely, or not at all, at grazed and cultivated parts of the watershed.

There was a significant difference in median relative abundance of Baetis sp. between sampling sites (KruskalWallis ANova by ranks test, $n=231 ; \mathrm{H}=81.61 ; P=0.001)$. Sites on forested and grazed parts of the watershed (Tiriytagoi, Logoman, Runguma, and Salt Spring), however, exhibited significantly low median relative abundances of Baetis sp., compared to the Sigotik Upstream, Highland Flowers, Nessuit Bridge and Confluence Upstream sites, which exhibited up to $75 \%$ dominance by Baetis sp. The relative abundance of Simulidae was significantly higher at Sigotik Downstream, compared to all other sites $(P=0.001)$. There also were significant differences between sites in the median relative abundances of Tanypodinae $(P=0.004)$, Tanytarsini $(P=$ $0.002)$, Hymanella sp. $(P=0.002)$, Lumbriculidae $(P=0.0001$ and Caenis sp. $(P=0.0068)$. However, these taxa did not show any discrimination of sites based on land use, unlike Baetis sp. and Simulidae. Forested parts of the watershed generally exhibited higher mean taxon richness, diversity and evenness, compared to those at cultivated parts, while the grazed sites exhibited intermediate means (Table 4). The Runguma and Salt Spring sites exhibited significantly higher taxon richness, compared to all the other sites $(P<0.05)$. Similarly, benthic macroinvertebrate diversity did not show a particular downstream trend. However, sites in the forested areas of the watershed (e.g. Runguma and Salt Spring) exhibited significantly higher mean diversities of benthic macroinvertebrates, compared to cultivated sites like Sigotik Upstream, Nessuit Bridge and Highland Flowers $(P<0.05$; Table 4$)$.

As expected, macroinvertebrate evenness showed contrasting patterns with dominance. It is worth noting that, although macroinvertebrate evenness followed the same trends as diversity and richness, differences between forested, grazed and cultivated sites were less distinct (Table 4). The Tiriytagoi site exhibited the highest mean evenness $(0.99 \pm 0.25)$ of benthic macroinvertebrates in the entire watershed, followed by the Salt Spring and Runguma sites. These three sites also did not differ significantly in 
mean evenness between each other $(P>0.05)$. Thus, the higher evenness of the distribution of benthic invertebrates was generally observed at the least-impacted sites, unlike sites in cultivated parts of the watershed, where the communities were dominated by a single taxon (usually Baetis sp. or Simulidae).

\section{Relationships between physicochemical factors and benthic macroinvertebrate composition and community structure}

Based on Spearman rank order correlations, several significant relationships were observed. Macroinvertebrate taxon richness showed positive and negative correlations with temperature and total phosphorus, respectively $(P<0.05$; Table 5). Similarly, macroinvertebrate taxa diversity showed positive and negative correlations with conductivity and TSS, respectively. Baetis sp. was positively and negatively correlated to TSS and conductivity, respectively $(P<0.05)$. Simulidae exhibited significant associations with organic nitrogen and $\mathrm{pH}$. The abundances of Helodidae, Leptophlebia sp., L. hirtum Fabricius and Potamon sp. were positively correlated to $\mathrm{DO}, \mathrm{pH}$ and $\mathrm{TOC}$, but negatively correlated to temperature, total phosphorus, total nitrogen, TSS and nitrites. Thus, Helodidae, Leptophlebia sp., L. hirtum Fabricius and Potamon sp. were clearly characteristic of clean, forested reference conditions in the watershed. They represent taxa with distributions restricted to the remaining

Table 4. Summary of mean $( \pm \mathrm{SE})$ community structure attributes for sample sites in the upper reaches of the River Njoro

\begin{tabular}{|c|c|c|c|c|c|}
\hline Land use & Sampling site & Taxon richness & Diversity & Evenness & Dominance \\
\hline \multirow[t]{2}{*}{ Forestry } & Salt Spring & $9.44 \pm 0.79$ & $0.71 \pm 0.04$ & $0.74 \pm 0.25$ & $0.25 \pm 0.03$ \\
\hline & Runguma & $10.06 \pm 0.74$ & $0.75 \pm 0.03$ & $0.76 \pm 0.25$ & $0.24 \pm 0.04$ \\
\hline \multirow[t]{2}{*}{ Grazing } & Logoman & $7.57 \pm 0.99$ & $0.58 \pm 0.05$ & $0.67 \pm 0.25$ & $0.28 \pm 0.04$ \\
\hline & Tiriytagoi & $6.35 \pm 0.80$ & $0.84 \pm 0.29$ & $0.99 \pm 0.25$ & $0.01 \pm 0.29$ \\
\hline Small-scale & Nessuit Bridge & $4.27 \pm 0.80$ & $0.40 \pm 0.05$ & $0.63 \pm 0.25$ & $0.31 \pm 0.06$ \\
\hline \multirow[t]{3}{*}{ agriculture } & Sigotik Upstream & $6.90 \pm 0.74$ & $0.38 \pm 0.04$ & $0.46 \pm 0.25$ & $0.54 \pm 0.05$ \\
\hline & Sigotik Bridge & $6.00 \pm 0.79$ & $0.51 \pm 0.05$ & $0.68 \pm 0.25$ & $0.32 \pm 0.05$ \\
\hline & Sigotik Downstream & $6.38 \pm 0.60$ & $0.43 \pm 0.04$ & $0.54 \pm 0.25$ & $0.46 \pm 0.05$ \\
\hline Intensive & Forest Camp & $6.81 \pm 0.56$ & $0.59 \pm 0.05$ & $0.70 \pm 0.25$ & $0.30 \pm 0.04$ \\
\hline \multirow[t]{2}{*}{ agriculture } & Highland Flowers & $7.18 \pm 0.76$ & $0.41 \pm 0.05$ & $0.50 \pm 0.25$ & $0.50 \pm 0.07$ \\
\hline & Confluence Upstream & $5.50 \pm 0.72$ & $0.50 \pm 0.05$ & $0.65 \pm 0.25$ & $0.35 \pm 0.05$ \\
\hline
\end{tabular}

Table 5. Spearman rank order correlation coefficients observed among physicochemical parameters, and between physicochemical parameters and some specific taxa and community structure attributes (all symbols and units are identical to previous tables; ${ }^{* *}$ Correlation is significant at $\alpha=0.01$; ${ }^{*}$ Correlation is significant at $\alpha=0.05$ ).

\begin{tabular}{lcccccccccc}
\hline Parameter & Temperature & TP & TN & TSS & $\mathrm{NO}_{2}-\mathrm{N}$ & $\mathrm{DO}\left(\mathrm{mg} \mathrm{L}^{-1}\right)$ & $\mathrm{O}-\mathrm{N}$ & Conductivity & $\mathrm{pH}$ & $\mathrm{TOC}$ \\
\hline $\mathrm{TP}$ & 0.12 & & $0.42^{*}$ & $0.58^{*}$ & 0.13 & 0.08 & -0.01 & $0.58^{*}$ & 0.57 & -0.32 \\
$\mathrm{Ph}$ & 0.12 & $0.57^{*}$ & 0.01 & 0.30 & 0.01 & 0.07 & -0.12 & 0.09 & 0.21 \\
Richness & $0.96^{* *}$ & $-0.93^{*}$ & -0.14 & -0.34 & $-0.51^{*}$ & 0.32 & -0.13 & 0.22 & 0.37 & 0.41 \\
Diversity & -0.32 & -0.22 & -0.34 & $0.97^{* *}$ & 0.01 & -0.20 & -0.34 & $-0.96^{* *}$ & -0.01 & 0.38 \\
Dominance & 0.15 & $0.86^{* *}$ & 0.28 & $-0.48^{*}$ & -0.29 & 0.27 & 0.27 & -0.09 & 0.19 & -0.35 \\
Baetis sp. & -0.37 & 0.10 & -0.24 & $0.88^{* *}$ & -0.36 & 0.38 & -0.23 & $-0.86^{* *}$ & $0.45^{*}$ & 0.11 \\
Simulidae & 0.35 & -0.17 & $0.79 *$ & -0.24 & -0.14 & $-0.48^{*}$ & $0.96^{* *}$ & -0.15 & $0.64^{*}$ & 0.01 \\
Tanypodinae & -0.04 & 0.21 & -0.12 & -0.06 & $-0.55^{*}$ & -0.02 & -0.10 & $0.79^{*}$ & 0.25 & 0.21 \\
Sphaeridae & $0.71^{*}$ & -0.17 & -0.03 & 0.33 & -0.13 & -0.22 & -0.02 & 0.10 & -0.12 & 0.11 \\
Potamon sp. & $-0.76^{*}$ & -0.25 & -0.31 & $-0.47^{*}$ & -0.39 & $0.83^{* *}$ & -0.24 & 0.47 & $0.44^{*}$ & $0.49^{*}$ \\
Helodidae & -0.27 & $-0.38^{*}$ & $-0.48^{*}$ & -0.18 & -0.11 & 0.04 & 0.04 & -0.14 & 0.08 & -0.11 \\
Lepidostoma hirtum Fabricius & -0.22 & -0.22 & -0.32 & -0.13 & $-0.38^{*}$ & -0.14 & 0.11 & -0.14 & -0.17 & 0.14 \\
\hline
\end{tabular}

DO, dissolved oxygen; TN, total nitrogen; TOC, total organic carbon; TP, total phosphorus; TSS, total suspended solids. 
unpolluted sections of the River Njoro watershed. However, Baetis sp. and Simulidae are characteristic of cultivated, nutrient-enriched and constantly disturbed parts of the upper River Njoro watershed.

\section{DISCUSSION Spatio-temporal variations in physicochemical factors in the upper River Njoro}

Water temperature showed a distinct pattern, with the sites at grazed and cultivated parts of the watershed exhibiting higher temperatures than the shaded, forested reference sites. This pattern agrees with the observation that, on a local scale, temperatures of streams vary in response to the intensity of vegetation cover (Wetzel 2001). As small streams, these sample sites were shallow, thereby having a high surface area to volume ratio that allows for fast heating of the stream water when exposed to the hot tropical sun. In contrast, the small, heavily canopied streams exhibited only very small temporal changes in temperature, often reflecting the temperature of forest soil (Wetzel 2001).

The elevated ammonia concentration exhibited at the grazed Logoman site is likely caused by comparatively higher inputs of decomposing animal dung visible in the water at the site. The concentration of animals on the land surface causes direct and indirect effects on aquatic ecosystems, the most obvious being additions of ammonia and nitrite as a consequence of increased run-off of animal waste into streams from grazed fields (Gammon et al. 2003). In their study, Gammon et al. (2003) investigated sites downstream of animal feed lots, finding they had elevated levels of ammonia, $\mathrm{pH}$ and turbidity. This observation apparently seems to be contrasted by the lower ammonia concentrations at the Tiriytagoi site, although this site is nearby and also heavily grazed. This can be partly explained by the length of the grazed stretch of stream at the Tiriytagoi site. Field surveys upstream of the Tiriytagoi site suggested that the concentration of cattle increased up to $10-\mathrm{km}$ upstream of the site. Given the high DO concentration in the river, it is possible that ammonia is actually generated from decomposing animal waste deposited on the stream, or else washed into the stream from the grasslands and then oxidized as the water flows downstream. This explanation is supported by the elevated nitrate concentration exhibited at the Tiriytagoi site, which could result from the oxidation of ammonia (Wetzel 2001). The $\mathrm{pH}$ recorded at the Tiriytagoi site was near a neutral value. A neutral $\mathrm{pH}$ increases the mineralization of ammonia (Allan 1995; Wetzel 2001).

Both grazed sampling sites exhibited ammonium concentrations much greater than the $0.018 \mathrm{mg} \mathrm{L}^{-1}$ mean calculated by Meybeck (1992) for unpolluted rivers. This shows that the grazed stretches of River Njoro are polluted by inputs of livestock manure. However, the spatial variations of other nutrients, especially nitrates and phosphates, seem to be associated more with crop farming land use, rather than grazing and forestry, in the upper River Njoro watershed. The mean nitrate concentration recorded at the Highland Flowers sampling site, for example, is almost double that recorded at the Salt Spring site. Similarly, the Confluence Upstream site exhibited significantly higher concentrations of total phosphorus, with large-scale crop farming of maize and beans. The dissolved inorganic phosphorus concentration often increases to levels of 0.05 and $0.1 \mathrm{mg} \mathrm{L}^{-1}$ from agricultural run-off (Wetzel 2001). Ormanik (1977) also reported an increase in phosphorus and nitrogen in agricultural run-off, compared to run-off from the landscape under indigenous forests.

This study shows a significant correlation between the total phosphorus and TSS concentrations, implying a common origin. It is likely that the implied common origin of phosphorus and TSS is cultivated fields. Compared to forest and grasslands, cultivated land is easily erodible because of reduced surface roughness and organic matter content (Wetzel 2001). It is usually rich in nutrients because of artificial fertilization to increase crop production. In general, the topography of the catchments influences the extent of erosion and subsequent export of nutrients (Allan 1995; Wetzel 2001). The upper reaches of River Njoro, being of a high slope, typically are more susceptible to erosion.

High TOC concentrations were observed at the densely forested stretches of the watershed (e.g. Runguma site), while low values were observed in cultivated, grazed and clear-felled areas (e.g. the Tiriytagoi, Logoman and Sigotik Upstream sites). This finding suggests that grazing and logging affect the level of organic matter supply, retention, transformation and release in streams. Terrestrial plants form much of the allochthonous organic matter inputs to aquatic ecosystems (Bretschko 1995b). These materials are transformed by microbial activity, then leached to the stream through groundwater and run-off (Wetzel 2001). Removal of terrestrial vegetation, such as by clear-cutting of forests in a drainage basin or removal of riparian vegetation for agriculture or grazing uses, reduces the inputs of organic matter to the soil, thereby reducing the quantity of TOC in run-off or groundwater inputs to streams (Allan 1995). Consequently, streams running through parts of the watershed with a sparse vegetation cover are expected to have low concentrations of organic matter suspended and dissolved in water. This is likely to have been responsible for the reduced levels observed in stream water from areas of the watershed experiencing grazing, deforestation and agriculture. 


\section{Spatio-temporal variations in composition, distribution and community structure of benthic macroinvertebrates}

The 70 taxa encountered in samples from the upper reaches of River Njoro, the majority of which were identified only to family level, show that they are rich in benthic macroinvertebrates. The composition of these taxa, however, is similar to those identified from similar streams elsewhere. For example, Baetis sp. and Simulidae comprised 69\% by number of all benthic taxa identified in this study. In his investigations of Sagana, Naro Moru, Sirimon and Barguret streams of Mount Kenya, Van Someren (1952) found that, at high altitudes, the river bed communities were completely dominated by the mayfly Baetis sp. and the blackfly Simulium sp., with all other taxa occurring in much smaller numbers. Repeat visits to these streams by Mathooko and Mavuti (1992) also reported similar findings. Investigating six Guinean streams, Dudgeon (1994) found that, in overall terms, Baetidae dominated the benthos. He also found that Simulidae did not form a large percentage of the benthos. The present findings, however, seem to differ from those of Ahmel-Abdallah et al. (2004) on upland streams of Tanzania, who observed that freshwater crabs (Potamon sp.) dominated the benthos.

The observed reduction in the diversity of benthic macroinvertebrates, particularly at cultivated sites, could be attributed to changes in habitat quality as more land in the watershed is converted to agriculture, and the riparian zone is eroded as a result of frequent trampling by livestock. Although L. hirtum, Sericostomatidae, Helodidae and Potamon sp., which are well-known shredders (AhmelAbdallah et al. 2004), were present in many sites, high abundances of these taxa occurred only at the Salt Spring and Runguma sites, with reduced abundances being observed at the Logoman and Forest Camp sites. Their presence at other sites might have been caused by downstream drift, especially over the wet season. This is supported by the fact that only a few or a single specimen was encountered, especially in sites along cultivated parts of the watershed.

The above observation suggests that food items (litter fall, wood debris that support their shredder-feeding behaviour) of high quality are only found at the least-impacted sites. In fact, a majority of the downstream sites have canopy interruptions from deforestation, riparian grazing or direct river use as watering points. In settled areas, every farm adjacent to the river must create an access path to the stream through which they pass with livestock to the only source of water.
As farms in the upper reaches of River Njoro are small (usually five acres or less), foot paths from farms on both sites of the river are numerous, increasing the cumulative areas of open canopy that allow sunlight to reach the stream. This increases the temperature variability, which can expand beyond evolutionary histories of a majority of shredder taxa because of their association with heavily canopied streams, whose temperatures vary less over time (Allan 1995). Furthermore, frequent disturbance of the streambed means that only a few taxa tolerant to constantly shifting sediments and bedrock can proliferate in large numbers, while a majority of the taxa occur only rarely. This impact is increased during rare storm events, when large quantities of sediments are eroded from cultivated farms and foot paths, and subsequently washed into streams. Suspended solids reaching streams can smoother the riverbed, flush away substrates and associated invertebrates, and increase the quantity of fine sediments in pools, which can be colonized only by a few specialized taxa (Bretschko 1995a). This helps explain the relatively higher variability in the invertebrate density when stretches of the river in cultivated and forested parts of the watershed are compared.

Forests, especially indigenous ones, serve to delay the rate of water delivery from the landscape and trap eroded sediments, thereby working to maintain relatively stable water flows (Carlisle et al. 2003). This allows for development of a rich and diverse invertebrate community (Wohl \& Carline 1996). Environmental stability is listed as a major factor controlling the structure of tropical ecosystems (Jacobsen \& Encalada 1998).

Diversity is a structural character of an ecosystem (Bretschko 1995a). High species diversity allows for complex population interactions involving energy transfer, competition and niche apportionment (Brower et al. 1990). It is generally expected that un-impacted sites contain diverse benthic communities (Jones et al. 2002). Anthropogenic disturbances from changes in land-use practices are known to affect invertebrate diversity patterns in streams draining modified catchments (Death 2000), often leading to a decrease in the total number of taxa, as well as a shift to a more unevenly distributed community wherein one or two taxa are numerically dominant (Jones et al. 2002; Carlisle et al. 2003). The high level of dominance by a few benthic taxa at sites experiencing agricultural impacts (e.g. the Sigotik Upstream, Sigotik Downstream and Highland Flowers sites), compared to evenly distributed taxa in presettlement areas (Runguma, Logoman and Salt Spring sites), suggests that human activities are already shaping benthic communities in the upper reaches of River Njoro. 
Dudgeon (1993) recorded a decrease in zoobenthic taxa colonizing artificial substrates placed in an impacted site, compared to a control site. In comparing impacted and un-impacted sites in that particular study, he found that reductions in zoobenthos densities and diversities were related to changes in stream sediments and increased suspended solid loads associated with agricultural activities. In a related experiment, he observed rapid reductions in density and diversity when macroinvertebrates were transferred to the impacted site, providing strong support for the detrimental effects of high TSS loads. Immediate reductions in the density of this type had earlier been attributed to catastrophic drift caused by shifting sediments (Culp et al. 1986). Erosion of land is likely to increase the quantity of fine sediments deposited in pools of impacted sections of the stream. Fine sediments are easily mobilized downstream (Wohl \& Carline 1996). Bretschko (1995a) recorded reductions in invertebrate densities in pools with finer sediments in River Njoro. He observed that the shifting nature of fine sediments in streams makes them less attractive for colonization by invertebrates, therefore always having a smaller number of invertebrates, compared to stable larger particles. In constantly disturbed streambeds, even larger particles are less attractive to colonization because their surfaces are covered by silt (Allan 1995). Silt-covered cobbles have less potential for colonization by periphyton whose microfilm is fed on by scrapping macroinvertebrates. At the Sigotik Bridge site, larger particles at riffles were brown in colour and less slippery in nature, providing evidence of low microbial colonization. Such substrates are typically less attractive to macroinvertebrate colonization (Allan 1995), which could explain why the invertebrate density was lower at the Sigotik sites.

The significant correlations observed in this study between TSS and dominance of macroinvertebrates by a few taxa clearly illustrate that mobilization of sediments from agricultural lands was responsible for reductions in numbers of seemingly sensitive taxa and the proliferation of Baetis sp. and Simulidae, the two dominant taxa. Coldwater organisms are generally known to be more sensitive to environmental changes (Griffiths 1996), thereby expected to respond quickly to environmental disturbances. Thus, this study shows that TSS, total phosphorus, organic nitrogen and conductivity are the main physicochemical factors controlling community structure, as well as the distribution of specific taxa in the upper reaches of the River Njoro. There is need for more research to study this observed pattern. The dominant taxa at impacted sites (i.e. Baetis sp. and Simulidae) observed in this study are known to have short regeneration times and rapid colonization rates (Hynes 1975), enabling them to cope with fluctuating environments and build up large populations opportunistically (Newbold et al. 1980). However, the significant correlations between Potamon sp., L. hirtum Fabricius and Helodidae with TOC, conductivity and $\mathrm{pH}$ show that these taxa, especially Helodidae and Potamon sp., can be used to monitor stream recovery, especially if riparian zone reclamation can be adopted as a conservation strategy to achieve a better watershed health.

Similarly, dominance, as a community structure index, as well as the abundance of Baetis sp. and Simulidae, can be used to monitor the deterioration of stream habitats and water quality in the upper reaches of the River Njoro. This is supported by the significant positive correlation between these two taxa with TSS and total nitrogen, variables associated with impact from grazing (Wohl \& Carline 1996) and cultivation (Allan 1995). As such, their dominance supports the thought that Baetis sp. and Simulidae are tolerant to agricultural impacts (Hynes 1960; Newbold et al. 1980). Thus, the significant positive correlation observed between the diversity of benthic invertebrates and TSS in this study implies that the diversity of benthic invertebrates is limited by suspended solid-generating activities. For the River Njoro, these activities are grazing and land cultivation. Further manipulative laboratory experiments to test our field observations could give useful patterns that can aid sustainable watershed management for all stakeholders.

\section{ACKNOWLEDGEMENTS}

We are greatly indebted to Global Livestock Collaborative Research Support Program (GL-CRSP) for funding this study. GL-CRSP is funded in part with funds from United States Agency for International Development and participating institutions. Andrew Kulecho helped in the laboratory analysis of water samples. Dr Thomas Ballatore of ILEC helped in proofreading our initial draft.

\section{REFERENCES}

Abdallah A. H., de Mazancourt C. \& Elinge M. M. et al. (2004) Comparative studies on the structure of an upland African stream ecosystem. Freshwat. Forum 21, 27-47.

Allan J. D. (1995) Stream Ecology: Structure and Function of Running Waters. Chapman \& Hall, London.

American Public Health Association (APHA). (1998) Standard Methods for Examination of Water and Wastewater, 20th edn. APHA, Washington, DC.

Baldyga T. J., Miller S. N., Driese K. L., Maina Gichaba C., \& Sivanpillai R. Land Cover Change Assessment within Kenya's Mau Forest Region Using Remotely Sensed Data. Accepted for publication in the African Journal of Ecology. 
Bretschko G. (1995a) Tropical river ecology initiative. Proceedings of the First Workshop on the Limnology of Njoro River, Egerton University, Kenya.

Bretschko G. (1995b) River/land ecotones: scales and patterns. Hydrobiologia 303, 83-91.

Brower J. E., Zar J. H. \& von Ende C. N. (1990) Field and Laboratory Methods for General Ecology. William C. Brown Publishers, New York.

Carlisle D. M., Stewart P. M. \& Butcher J. T. (2003) Macroinvertebrate assemblages associated with patterns in land use and water quality. In: Biological Response Signatures: Indicator Patterns Using Aquatic Communities (ed. T. P. Simon) pp. 271-86. CRC Press, Boca Raton, FL.

Culp J. M., Wrona F. J. \& Davies R. W. (1986) Response of stream benthos and drift to fine sediment deposition versus transport. Can. J. Zool. 64, 1345-51.

Death R. G. (2000) The effect of land use on the species-area relationships in benthic stream invertebrates. Verh. Int. Ver. Theor. Angew. Limnol. 27, 2519-22.

Dudgeon D. (1993) The effects of spate-induced disturbance, predation and environmental complexity on macroinvertebrates in a tropical stream. Freshwat. Biol. 30, 189-97.

Dudgeon D. (1994) The influence of riparian vegetation on macroinvertebrate community structure and functional organization in six new guinea streams. Hydrobiologia 294, 65-85.

Edington J. M. \& Hildrew A. G. (1995) Caseless caddis larvae of the British Isles: a revised key with ecological notes. Freshwater Biological Association, Cumbria, UK. Scientific publication no. 53. $136 \mathrm{p}$.

Gammon J. R., Wayne C. F. \& Simon T. P. (2003) Patterns in water quality and fish assemblages in three central Indiana streams with emphasis on animal feed lot operations. In: Biological Response Signatures: Indicator Patterns Using Aquatic Communities (ed. T. P. Simon) pp. 373-419. CRC Press, Boca Raton, FL.

Gore J. A. \& Shields D. Jr. (1995) Can large rivers be restored? Bioscience 45, 142-52.

Griffiths R. W. (1996) BioMAP: Concepts, protocols and sampling procedures for southwestern region of Ontario. BioMAP Report SWR-1. Ministry of Environment and Energy, Southern Region, Ontario.

Hynes H. B. N. (1960). The Biology of Polluted Waters. Liverpool University Press, Liverpool. 202 p.

Hynes H. B. N. (1975) The stream and its valley. Verh. Int. Ver. Theor. Angew. Limnol. 19, 1-15.

Jacobsen D. \& Encalada A. (1998) The macroinvertebrate fauna of Ecuadorian highland streams in the wet and dry season. Arch. Hydrobiol. 142, 53-70.
Jones C., Palmer R. M., Matkaluk S. \& Walters M. (2002) Watershed Health Monitoring: Emerging Technologies. CRC Press, Boca Raton, FL.

Mathooko J. M. \& Mavuti K. M. (1992) Composition and seasonality of benthic invertebrates and drift in the Naro Moru River, Kenya. Hydrobiologia 232, 47-56.

Meybeck M. (1992) Carbon, nitrogen and phosphorus transport by world rivers. Am. J. Sci. 282, 401-50.

Newbold J. D., Erman D. C. \& Roby K. B. (1980) Effects of logging on macroinvertebrates in streams with and without buffer strips. Can. J. Fish. Aquat. Sci. 37, 107685.

Ormanik J. M. (1977) Nonpoint Source-Stream Nutrient Level Relationships: A Nationwide Study. EPA-600/3-77105. US Environmental Protection Agency, Corvallis, OR.

Rosenbereg D. \& Resh V. (eds). (1992) Feshwater Biomonitoring and Benthic Macroinvertebrates. Chapman \& Hall, New York.

Savage A. A. (1989) Adults of the British aquatic Hemiptera Heteroptera: A key with ecological notes. Freshwater Biological Association, Cumbria, UK. Scientific publication no. 50.176p.

Simon T. P. (2003) Biological Response Signatures: Toward the Detection of Course-and-effect and Diagnosis in Environmental disturbance. Pages 3-12 in T. P. Simon (ed.). Biological Response Signatures: Indicator Patterns using Aquatic Communities. CRC Press, Boca Raton. $576 \mathrm{p}$.

StatSoft Inc. (2001) STATISTICA for Windows. StatSoft Inc., Tulsa, OK. http://www.statistica.com.

van Someren V. D. (1952) The Biology of Trout in Kenya Colony. River Research and Development Centre, Game Department, Kenya.

Wallace I. D., Wallace B. \& Philipson G. N. (1990) A key to the case-bearing caddis larvae of Britain and Ireland. Freshwater Biological Association, Cumbria, UK. Scientific publication no. 51. 240p.

Wells F., Metzeling L. \& Newall P. (2002) Macroinvertebrate regionalisation for use in the management of aquatic ecosystems in Victoria, Australia. Environ. Monit. Assess. $\mathbf{7 4}, 271-94$.

Wetzel R. G. (2001) Limnology: Lake and River Ecosystems, 3rd edn. Academic Press, San Diego, CA.

Wohl N. E. \& Carline R. F. (1996) Relations among riparian grazing, sediment loads, macroinvertebrates in streams with and without buffer strips. Can. J. Fish. Aqaut. Sci. 37, 1076-85.

Zar J. H. (1996) Biostatistical Analysis, 2nd edn. Prentice Hall, Englewood Cliffs, NJ. 